\section{Nomenclature of Salmonella}

To the bacteria now known as salmonellae, early bacteriologists applied, in Latinised form, epithets intended to indicate either the importance of these bacteria in disease production (e.g., Bacterium typhi, the agent of typhoid fever in man) or their association with particular animal hosts (e.g., Bacillus gallinarum, the agent of fowl typhoid in hens). That eminently sensible approach to nomenclature was discarded when it emerged that some salmonellae were not hostspecific (e.g., Bacillus typhi murium, the agent of mouse typhoid) and that others did not cause the diseases that first inspired their names (e.g., Bacillus cholerae suis, the supposed agent of hog cholera). ${ }^{1}$

\section{The Kauffmann-White scheme}

Thereafter, the most significant advance in the accurate definition of salmonellae of importance in human and veterinary medicine emerged from the pioneering serological studies of White, later amplified by Kauffmann. In the Kauffmann-White scheme ${ }^{2}$ which was, and is, intended to be a manual for everyday diagnostic use, each antigenically distinguishable type of Salmonella is recognised by its possession of particular $\mathrm{O}$ (cell wall) and $\mathrm{H}$ (flagellar) antigens; many, but not all, salmonella cultures express in alternate phases flagella of two different antigenic types ( $\mathrm{H} 1$ and $\mathrm{H} 2)$ and a very few of them produce Vi (capsular) antigen. Thus, each salmonella serotype is recognised by its unique combination of antigens (its antigenic formula). Unlike serotypes of most other bacteria that are described by their antigenic formulae alone (e.g., Escherichia coli serotype $\mathrm{O} 16: \mathrm{K} 1: \mathrm{H} 6$ ), salmonella serotypes have traditionally been given names which were accorded species status. Thus, for example, $S$. enteritidis $(1,9,12: \mathrm{g}, \mathrm{m}:-), S$. gallinarum $(1,9,12:-:-), S$. typhi $(9,12:[V i]: \mathrm{d}:-)$ and $S$. typhimurium $(1,4,[5], 12: \mathrm{i}: 1,2)$ became the accepted "species" names for the salmonellae whose antigenic formulae are shown. In 1925, only 20 salmonella species were known. ${ }^{2}$ An early pioneer of the serological approach commented then that "In addition to the limited series of commonly occurring forms recognised, there occur others of local or temporary importance and a larger - perhaps very large - number of rare types which come to light from time to time"; 3 even he, surely, could never have envisaged that by 1988, c. 2250 serotypes would have been recorded. ${ }^{4}$

The descriptive naming of salmonellae was replaced by a novel practice whereby newly identified serotypes were named after the place of their first isolation. Many exotic names emerged, e.g., $S$. adelaide, $S$. banana, S. caracas, S. dakar, S. entebbe and others, ${ }^{1,4}$ sometimes of more interest geographically than diagnostically or taxonomically. Some authorities wondered if serotyping had been carried to such an unjustifiable extreme that it was in danger of being used, not as a diagnostic tool, but as an end in itself, and expressed their doubts about according equal species ranking to major pathogens of worldwide distribution, e.g., $S$. typhi, and to rarely isolated serotypes of doubtful clinical significance. ${ }^{5}$ Several brave attempts were made over the years to limit the plethora of salmonella "species" but there were disagreements about appropriate nomenclature. One successful proposal was that of Ewing ${ }^{6}$ who named only three species: $S$. cholerae-suis, $S$. typhi and $S$. enteritidis, a "catch-all" species embracing all other serotypes. In that scheme, serotype $S$. typhimurium became $S$. enteritidis serotype (ser.) Typhimurium and other serotypes were similarly named. However, $S$. enteritidis became $S$. enteritidis ser. Enteritidis and led inevitably to confusion between the serotype and the species. Nevertheless, that style of nomenclature, excellently reviewed by Farmer et al., ${ }^{7}$ remained popular for some years, especially in the USA.

\section{The influence of modern taxonomy}

The application of newer methods, such as numerical and DNA-DNA re-association studies, to the taxonomy of salmonellae indicates that all serotypes of Salmonella and those of the former genus Arizona belong to one species comprising seven subspecies that are distinguishable by biochemical tests. ${ }^{8-10}$ By strict application of the rules of nomenclature, the single species should be named $S$. choleraesuis, a historic name formerly used, unfortunately, to designate a serotype. To avoid ambiguity, the alternative species name $S$. enterica was proposed, ${ }^{11}$ a suggestion with considerable merit because no serotype had ever been so named. Like species, subspecies merit taxonomic ranking and the names proposed for the subspecies of S. enterica are shown (table). ${ }^{11}$ However, further types below subspecies are not subject to the strictures of the Bacteriological Code. Put simply, serotypes have no more status than biotypes, phage types or other differential types and should not be styled as if they were species.

\section{Named serotypes in subspecies I}

The traditional practice of naming salmonella sero- 
Table. Subspecies of Salmonella enterica

\begin{tabular}{|c|c|c|c|c|}
\hline $\begin{array}{c}\text { Subspecies } \\
\text { no. }\end{array}$ & Name & \multicolumn{3}{|c|}{ Examples of serotype designations* } \\
\hline I & enterica & Choleraesuis & Enteritidis & Typhi \\
\hline II & salamae & $4,12: b: 1,5$ & $13,23: 1, w: e, n, x$ & $28: \mathrm{g}, \mathrm{s}, \mathrm{t}: \mathrm{e}, \mathrm{n}, \mathrm{x}$ \\
\hline IIIa $\dagger$ & arizonae & $\ddagger 13,22: z_{4}, z_{23}:-$ & $17: z_{38}:-$ & 42:r:- \\
\hline IIIb $\dagger$ & diarizonae & $11: 1, \mathbf{v}: \mathbf{z}$ & $16: k: z$ & $43: r: e, n, x, z_{15}$ \\
\hline IV & houtenae & $6,14: \mathrm{z}_{4}, \mathrm{z}_{23}:-$ & $40: \mathrm{m}, \mathrm{t}:-$ & $48: z_{29}:-$ \\
\hline $\mathrm{V} \S$ & bongori & $1,40: z_{35}:-$ & $44: r:-$ & $48: z_{35}:-$ \\
\hline VI & indica & $\overrightarrow{6}, 7: z_{41}: 1,7$ & $11: b: 1,7$ & $1,6,14,25: a: e, n, x$ \\
\hline
\end{tabular}

\footnotetext{
* Following the recommendation of Le Minor and Popoff, ${ }^{4}$ serotypes of S. enterica ssp. enterica (I) are named; those of subspecies II-VI are designated by antigenic formulae.

$\uparrow$ Subspecies IIIa and IIIb, formerly classified as Arizona.

$\ddagger$ Serotypes of subspecies IIIa, IV and V are monophasic (H1 only).

$\S$ Evidence suggests that subspecies V may constitute a second species, for which the name $S$. bongori has been proposed. ${ }^{15}$
}

types has been successful and these well-known names probably conjure up for non-experts something epidemiologically more meaningful than that of their corresponding antigenic formulae. Again, the system is so well understood and widely accepted in many areas of medical microbiology, epidemiology and public health that to abandon it now would be unacceptable. However, the formal presentation ${ }^{11}$ of any named salmonella serotype - e.g., S. enterica ssp. enterica serotype Typhimurium - is so cumbersome that it surely has to be restricted for use in specialist papers. Something simpler is needed for our everyday communuication and routine reporting of clinical isolates. What are the possibilities? Serotypes could still be named artificially as if they were species, e.g., $S$. typhimurium, or, more correctly, they could be denoted as Agona, Choleraesuis, Enteritidis, Goldcoast, Livingstone, Typhi, Urbana etc. ${ }^{4,7,11,12}$ Hence, simple designations acceptable for routine reporting of serotypes would include Salmonella serotype (ser.) Typhimurium, Salmonella Typhimurium or even Typhimurium. Most $(>99 \%)$ salmonellae isolated from man belong to subspecies $I^{7,13}$ the only one for which named serotypes would be retained. Accordingly, these proposals, if accepted, would have particular implications for medical microbiologists, not least that naming a serotype implied its membership of subspecies I.

\section{Serotypes in subspecies II-VI}

How then are serotypes in other subspecies to be labelled? Serotypes in subspecies IIIa and IIIb, the former genus Arizona, were never named; nor, since
1966, were those from subspecies II and IV. However, names had been given before 1966 to some serotypes in subspecies II and IV and to others later reclassified in the new subspecies V and VI. The designation of serotypes in subspecies II-VI, therefore, has been inconsistent. It is now recommended ${ }^{11}$ that serotypes in subspecies II-VI should be anonymous, designated instead by their antigenic formulae preceded by a subspecies number. Thus, $S$. sofia in subspecies II would become not, as might have been expected, Salmonella serotype Sofia but II 1,4,12,27:b:[e,n,x] (for other examples, see the table). Consequent upon this recommendation, all extant serotype names from subspecies II-VI have been deleted in the most recent edition of the Kauffmann-White scheme. ${ }^{4}$

Whilst perhaps difficult for non-experts to appreciate, the proposed changes should be welcomed because they offer at last an ordered, unified approach to the future naming of salmonellae that would be denied us by strict adherence to the customs dictated by historic precedent. Nevertheless, whether or not bacteriologists accept the single species concept of Salmonella, they may continue to designate salmonella serotypes as if they were species and name serotypes from subspecies II-VI because, in the absence of a formal ruling, both styles are correct.

"What's in a name? That which we call a rose by any other name would smell as sweet". ${ }^{14}$ Whether Salmonella Typhimurium seems as sweet as $S$. typhimurium will no doubt influence habits and the preferred method will eventually emerge.

D. C. OLD

Department of Medical Microbiology, University of Dundee Medical School, Ninewells Hospital, Dundee DD1 9SY.

\section{References}

1. Le Minor L. Genus III. Salmonella Lignieres 1900, 389. In: Kreig NR, Holt JG (eds) Bergey's manual of systematic bacteriology, vol. 1. Baltimore, Williams and Wilkins. 1984: 427-458.

2. Kauffmann F. Enterobacteriaceae, 2nd edn. Copenhagen, Munksgaard. 1954: 19-146.

3. White PB. The salmonella group. In: Fildes $P$, Ledingham JCG (eds) A system of bacteriology in relation to medicine, vol. 4 London, HMSO. 1929: 86-158.

4. Le Minor L, Popoff MY. Antigenic formulas of the Salmonella serovars, 5th rvn. Paris, WHO Collaborative Centre for Reference and Research on Salmonella, Institut Pasteur, France. 1988: 1-146.

5. Wilson GS, Miles AA. Salmonella. In: Topley and Wilson's 
principles of bacteriology and immunity, 4 th edn, vol. 1 . London, Arnold. 1955: 801-856.

6. Ewing WH. The nomenclature of Salmonella, its usage and definitions for the three species. Can J Microbiol 1972; 18: 1629-1637.

7. Farmer JJ, McWhorter AC, Brenner DJ, Morris, GK. The Salmonella-Arizona group of Enterobacteriaceae: nomenclature, classification and reporting. Clin Microbiol Newsletter 1984; 6: 63-66.

8. Crosa JH, Brenner DJ, Ewing WH, Falkow S. Molecular relationships among the Salmonelleae. J Bacteriol 1973; 115: $307-315$.

9. Le Minor L, Véron M, Popoff MY. Taxonomie des Salmonella. Ann Microbiol (Paris) 1982; 133B: 223-243.

10. Le Minor L, Véron M, Popoff MY. Proposition pour une nomenclature des Salmonella. Ann Microbiol (Paris) 1982; 133B: $245-254$.
11. Le Minor L, Popoff MY. Designation of Salmonella enterica sp. nov., nom. rev., as the type and only species of the genus Salmonella. Int J Syst Bacteriol 1987; 37: 465-468.

12. Old DC. Salmonella. In: Parker MT, Duerden BI (eds) Topley and Wilson's principles of bacteriology, virology and immunity, 8th edn, vol. 2. London, Arnold. 1990: 469-493.

13. Le Minor L, Le Minor S, Grimont PAD. Rapport quadriennal du Centre national des Salmonella sur l'origine et la répartition en sérotypes des souches isolées en France continentale au cours des années 1980 à 1983. Rev Epidemiol Sante Publ 1985: 33: 13-21.

14. Shakespeare W. Romeo and Juliet. Act II, scene ii.

15. Reeves MW, Evins GM, Heiba AA, Plikaytis BD, Farmer JJ. Clonal nature of Salmonella typhi and its genetic relatedness to other salmonellae as shown by multilocus enzyme electrophoresis, and proposal of Salmonella bongori comb. nov. J Clin Microbiol 1989: 27: 313-320. 